\title{
A Proximal Promoter Domain Containing a Homeodomain-Binding Core Motif Interacts with Multiple Transcription Factors, Including HoxA5 and Phox2 Proteins, and Critically Regulates Cell Type-Specific Transcription of the Human Norepinephrine Transporter Gene
}

\author{
Chun-Hyung Kim, Dong-Youn Hwang, Jae-Joon Park, and Kwang-Soo Kim \\ Molecular Neurobiology Laboratory, McLean Hospital, Harvard Medical School, Belmont, Massachusetts 02478
}

\begin{abstract}
Expression of the norepinephrine transporter (NET), which mediates the reuptake of norepinephrine into presynaptic nerve terminals, is restricted to noradrenergic (NA) neurons. We have demonstrated previously that the $9.0 \mathrm{~kb}$ upstream sequences and the first intron residing in the $5^{\prime}$ untranslated area are critical for high-level and NA cell-specific transcription. Here, using transient transfection assays, we show that $4.0 \mathrm{~kb}$ of the $5^{\prime}$ upstream sequences contains sufficient genetic information to drive reporter gene expression in an NA cell type-specific manner. Three functional domains appear to be potentially important for the regulation of human NET ( $h N E T$ ) gene transcription: an upstream enhancer region at -4.0 to $-3.1 \mathrm{~kb}, \mathrm{a}$ proximal domain at -133 to $-75 \mathrm{bp}$, and a middle silencer region between these two domains. DNase I footprinting analysis of the proximal promoter region shows that a subdomain at -128 to $-80 \mathrm{bp}$ is protected in a cell-specific manner. We
\end{abstract}

provide evidence that multiple protein factors interact with the proximal promoter domain to critically regulate the transcriptional activity of the $h N E T$ gene. In the middle of this proximal subdomain resides a homeodomain (HD)-binding core motif, which interacts with HD factors, including Phox2a and HoxA5, in an NA-specific manner. Cotransfection analyses suggest that HoxA5 and Phox2a may transactivate the hNET gene promoter. Together with previous studies indicating direct activation of dopamine $\beta$-hydroxylase transcription by $P h o x 2 a / 2 b$, the present results support a model whereby Phox2 proteins may coordinately regulate the phenotypic specification of NA neurons by activating both NA biosynthetic and reuptake genes.

Key words: norepinephrine transporter; promoter; noradrenergic neuron; cell type-specific transcription; cis-acting element; homeodomain; Phox2a; HoxA5
The norepinephrine transporter (NET) mediates norepinephrine (NE) reuptake into presynaptic nerve endings (Axelrod and Kopin, 1969). NET is an important target of antidepressant drugs, including desipramine and reboxetine (Owens et al., 1997; Sacchetti et al., 1999), and illicit drugs such as cocaine and amphetamine (Pacholczyk et al., 1991). Levels of NET in brain noradrenergic neurons appear to be regulated to maintain normal concentrations of NE in the noradrenergic synapse. For example, reserpine treatment, which significantly depletes $\mathrm{NE}$, decreases NET density in the rat cerebral cortex (Lee et al., 1983) and steady-state levels of NET mRNA in the locus ceruleus (Cubells et al., 1995). NET density in the rat cerebral cortex is increased by the administration of a monoamine oxidase inhibitor known to elevate NE availability in synapses (Lee et al., 1983). Using the $\mathrm{NET}^{-/-}$mice, $\mathrm{Xu}$ et al. (2000) have further shown that NET is involved in NE clearance as well as presynaptic and postsynaptic $\mathrm{NE}$ homeostasis, suggesting that regulation of NET expression contributes to the homeostasis of NE in the noradrenergic syn-

Received Aug. 16, 2001; revised Jan. 8, 2002; accepted Jan. 22, 2002.

This work was supported by National Institutes of Health Grant MH48866 and a National Alliance for Research on Schizophrenia and Depression independent award (K.-S.K.). We thank Dr. Donna Wong and members of the Molecular Neurobiology Laboratory for critically reading this manuscript. We also thank Dr. J. F. Brunet and Dr. D. J. Drucker for the generous gift of antibodies.

Correspondence should be addressed to Kwang-Soo Kim, Molecular Neurobiology Laboratory, McLean Hospital, Harvard Medical School, 115 Mill Street, Belmont, MA 02478. E-mail: kskim@mclean.harvard.edu.

Copyright (C) 2002 Society for Neuroscience $0270-6474 / 02 / 222579-11 \$ 15.00 / 0$ apse. The contribution of NET to homeostasis may be of great clinical interest, because dysregulation of noradrenergic neurotransmission has been associated with affective disorders (Ressler and Nemeroff, 1999, 2000) and cognitive disorders (Friedman et al., 1999). In vivo studies of postmortem brain tissues have demonstrated that central noradrenergic neurons in the locus ceruleus appear disrupted in suicide victims compared with normal control subjects (Ordway et al., 1994). A similar disruption of the noradrenergic system has been reported in rat models of depression and can be rectified by tricyclic antidepressant administration (Papp et al., 1994). Finally, a mutation in the NET transmembranespanning domain has recently been reported to be associated with autonomic disorders such as orthostatic intolerance (Shannon et al., 2000).

$\mathrm{NET}$ expression in the rat CNS is restricted to noradrenergic neurons in the A1, A2, A4, A5, A6, and A7 regions of the brain (Lorang et al., 1994; Comer et al., 1998; Schroeter et al., 2000; Phillips et al., 2001). Outside the nervous system, some nonneuronal tissues, such as the placental syncytiotrophoblast (Ramamoorthy et al., 1993), also express NET mRNA. The highest density of NET-expressing cells is observed in the locus ceruleus (A6 cell group). In noradrenergic cell groups, most but not all NET-positive cells also express high labels of dopamine $\beta$-hydroxylase (DBH). These results indicate that NET and DBH are frequently, but not exclusively, coexpressed in noradrenergic neurons (Lorang et al., 1994; Schroeter et al., 2000). In the PNS, NET is expressed in the superior cervical ganglion (Nishimura et 
al., 1999; Schroeter et al., 2000). Among non-neuronal cells, NET expression has been shown in adrenal chromaffin cells and in ependymal cells lining the ventricular surfaces in the CNS (Schroeter et al., 2000; Phillips et al., 2001). In contrast, serotonergic neurons of the dorsal raphe, dopaminergic neurons of the substantia nigra, and adrenergic neurons in C1-3 cells do not contain NET-positive neurons, suggesting that the distribution of NET in the CNS and PNS closely associates with that of NEcontaining cell bodies. Taken together, these findings indicate that NET is essential for phenotypic specification and thus is a hallmark protein of noradrenergic neurons.

$\mathrm{DBH}$ is another protein that is selectively expressed in noradrenergic and adrenergic neurons. Both in vivo transgenic and in vitro cell culture studies demonstrate that relatively short upstream sequences of the $D B H$ gene are sufficient for driving noradrenergic-specific reporter gene expression (Shaskus et al., 1992; Ishiguro et al., 1993; Hoyle et al., 1994). The human DBH promoter was systematically characterized by electrophoretic mobility shift assay, DNase I footprinting, deletional, and sitedirected mutational analyses (Ishiguro et al., 1993; Kim et al., 1994; Seo et al., 1996; Yang et al., 1998b). Two cis-regulatory elements, the homeodomain-binding sites of the composite promoter (domain IV) and domain II, which are exclusively active in noradrenergic cell lines and thus essential for the cell-specific promoter activity of the $D B H$ gene, were identified (Seo et al., 1996; Kim et al., 1998; Yang et al., 1998b). Of note, both cisregulatory elements were shown to be binding sites for the pairedlike homeodomain protein Phox2a, also known as Arix for its rat homolog (Zellmer et al. 1995), which is critical for the development of several major noradrenergic cell groups, including the locus ceruleus (Morin et al., 1997). Given that DBH is primarily coexpressed with NET, the above findings raise the question of whether the same molecular mechanisms may underlie the noradrenergic cell type-specific expression of the NET gene.

Despite the pathophysiological and phenotypical importance of NET in neurotransmission, little is known about the molecular mechanisms underlying its expression. A cDNA encoding human NET (hNET) was isolated by an expression cloning approach (Pacholczyk et al., 1991), and subsequently, cDNAs for the bovine and the rat NET genes were cloned on the basis of their sequence homologies (Lingen et al., 1994; Bruss et al., 1997), which made possible the molecular approaches of NET gene regulation. To begin to elucidate the molecular mechanisms controlling expression of the $h N E T$ gene, we previously characterized the structural organization of the $5^{\prime}$ upstream region of the $h N E T$ gene (Kim et al., 1999). Approximately $9 \mathrm{~kb}$ of the $5^{\prime}$ flanking sequences of the $h N E T$ gene confers cell specificity, whereas the first intron is required for high-level reporter gene expression. A systematic dissection of the first intron demonstrated that it enhances the promoter activity in an orientation- and position-dependent manner and that an E-box motif residing at the junction of the first exon and intron is critical not only for promoter-enhancing activity but also for the splicing of the first intron (Kim et al., 2001). In the present study, we demonstrate that $4.0 \mathrm{~kb}$ of the $5^{\prime}$ upstream sequences contains sufficient genetic information required for noradrenergic-specific expression of the $h N E T$ gene. Three domains have been identified to be potentially important for the regulation of $h N E T$ gene transcription: an upstream enhancer region between -4.0 and $-3.1 \mathrm{~kb}$, a proximal domain between -133 and $-75 \mathrm{bp}$, and a middle silencer domain between these two domains. Furthermore, our functional and DNA-binding analyses indicate that the proximal domain contains several cis- regulatory elements in tandem. Among these cis-elements, the middle one containing a homeodomain core motif (ATTA) interacts with Phox2a and HoxA5 and critically controls the noradrenergic (NA)-specific transcriptional activity of the hNET gene.

\section{MATERIALS AND METHODS}

Plasmid DNA constructions. The construction of pNET9000CAT was described previously (Kim et al., 1999). The $4 \mathrm{~kb}$ EcoRI-BamHI fragment in pNET9000CAT was subcloned into the pBluescript II-KS(+) vector (Stratagene, La Jolla, CA) to make pKS4000. Then SalI and BamHI were used to recover the $4 \mathrm{~kb}$ DNA fragment from pKS4000 (SalI was derived from the polylinker of pBluescript), and it was cloned into the SalI-BamHI sites of pBLCAT3-1 containing chloramphenicol acetyltransferase (CAT) as the reporter (Kim et al., 1998; Yang et al., 1998b), yielding pNET4000CAT. To generate a construct containing promoter and the first intron, the intronic sequence was amplified by PCR using the sense primer (5'-ACC AGG GAT CCC CTC GCC GCC GGA CAC - $\left.3^{\prime}\right)$ and the antisense primer (5'-TCG CGG A TC CGA ATT CTG GCG AGA GGA ACT TTA CCG G-3'), digested with BamHI, and subcloned into pNET4000CAT digested with BamHI, which corresponds to residues at +159 to +164 (Kim et al., 1999). The BamHI site in the sense primer is a natural site in the $5^{\prime}$ untranslated region of the hNET gene (Kim et al., 1999), and that in the antisense primer was artificially inserted to facilitate the cloning step. The resulting new construct, designated pNET4000(i)CAT, contains the full sequence of the first intron as well as the surrounding nucleotides, which were confirmed by sequence analysis. Serial deletion constructs were produced from pNET4000(i)CAT by the exonuclease III and mung bean nuclease method (Guo et al., 1983; Henikoff, 1984). Briefly, the plasmid pNET4000(i)CAT was digested with SphI and SalI, generating 3' and 5' extensions, respectively. DNA was extracted with phenol-chloroform and was digested with exonuclease III at $30^{\circ} \mathrm{C}$. Aliquots from the exonuclease III digestion were removed at $30 \mathrm{sec}$ intervals and added to mung bean nuclease-containing tubes to remove single-stranded tails. Blunt-ended deletion fragments were circularized by T4 DNA ligase, and the deletion mutant constructs were transformed into a competent DH5 $\alpha$ Escherichia coli strain. All 5' deletion constructs (Fig. $1 A$ ) were verified by sequencing and named according to the position of the $5^{\prime}$ end of the inserted sequence relative to the transcription initiation site. Base substitutions in the homeodomain (HD) motif between -128 and -80 were introduced into pNET4000(i)CAT using the Transformer mutagenesis kit (Clontech, Palo Alto, CA) according to the manufacturer's instructions. The following oligonucleotides were used in the mutagenesis procedure: selection primer, 5'-TAC TGA GAG TGC ACC CGC GGC GGT GTG AAA TAC C-3'; and HD mutant (HDm) primer, 5'-CCG CGC TGT CAG TCT CCA GCA GCG CTA ACA GGC TCC AG-3' (underscores indicate the mutated bases). The site-directed mutant constructs were verified by restriction enzyme and sequence analysis. The TATA-CAT plasmid has been described previously (Yang et al., 1998b). Reporter constructs containing multiple copies of a DNA fragment (PR) covering -128 to -80 bp of hNET promoter, which encompass the nucleotide sequences of the footprinted proximal domain, were generated as follows. Double-stranded DNA containing -128 to -80 bp was generated by annealing the sense and antisense PR oligonucleotides and self-ligated to produce multimers of PR. The multimers were blunt-ended and inserted upstream of the TATA sequence of TATA-CAT plasmid. Each clone was sequenced, and those containing five copies of PR in the forward orientation were used for the studies that follow. An 813 bp coding fragment of HoxA5 was produced by reverse transcription (RT)PCR from mouse CATH.a poly $\left(\mathrm{A}^{+}\right)$RNA using the primers 5'-AAA AAG GAT CCG CCA TGA GCT CTT ATT TTG TAA ACT CAT TTT G-3' and 5'-AAA AAC TCG AGT CAG GGG CGG AAA GCC CCC CCT GCC GCG GC-3'. The PCR fragment was digested with Bam HI and $X$ hoI and cloned into the pCDNA3.1 (Invitrogen, Carlsbad, CA) eukaryotic expression vector containing the cytomegalovirus (CMV) promoter to produce pCMVHoxA5. A $1041 \mathrm{bp}$ fragment of isl-1 cDNA was prepared by RT-PCR from SK-N-BE(2)C poly $\left(\mathrm{A}^{+}\right)$RNA using the primers 5'-AAA AAG GAT CCG CCA TGG GAG ATC CAC CAA AAA AAA AAC G-3' and 5'-AAA AAC TCG AGT CAT GCC TCA ATA GGA CTG GCT AC-3'. The amplified PCR product was digested with BamHI and XhoI and subcloned into the pCDNA3.1 cut with same enzymes, resulting in pCMVisl-1. PRc/Phox $2 \mathrm{a}$ and $\mathrm{pRc} /$ Phox $2 b$, which contain the full-length cDNA for Phox $2 a$ and Phox $2 b$, respectively, have been described previously (Valarche et al., 1993; Yang 
et al., 1998b). The nucleotide sequences for HoxA5 and isl-1 cDNAs were confirmed by sequence analysis.

Cell culture and transient transfection assays. The human neuroblastoma SK-N-BE(2)C and SK-N-BE(2)M17 cell lines were maintained as described previously (Ishiguro et al., 1993; Kim et al., 1994) and used as the NET-positive system. These cell lines express all biosynthetic enzymes required for NE synthesis and produce NE. HeLa, HepG2, and C6 cells were grown in DMEM supplemented with $10 \%$ fetal calf serum (Hyclone, Logan, UT), streptomycin, and penicillin and used as the NETnegative system. Transfection was performed by calcium phosphate coprecipitation as described previously (Ishiguro et al., 1993; Kim et al., 1994). Plasmids for transfection were prepared using Qiagen (Santa Clarita, CA) columns. For the SK-N-BE(2)C and SK-N-BE(2)M17 cell lines, each $60 \mathrm{~mm}$ dish was transfected with an equimolar amount $(0.5$ pmol) of each reporter construct, $1 \mu \mathrm{g}$ of $\mathrm{pRSV}-\beta$-gal, varying amounts of the effector plasmid, and pUC19 plasmid to a total of $5 \mu \mathrm{g}$ of DNA. For the HeLa, HepG2, and C6 cell lines, twice as much DNA was used, because the transfection efficiency was lower. To compare NET promoter activity in NET-positive and -negative cell lines, CAT activity driven by the reporter constructs was compared with that driven by the pRSV-CAT plasmid, which contains the Rous sarcoma virus (RSV) enhancer/promoter. Because of the strong promoter activity of the RSV enhancer/ promoter, a 0.1 molar amount $(0.05$ or $0.1 \mathrm{pmol})$ was used for the pRSV-CAT plasmid in the transient transfection assays. For cotransfection analysis, a half-molar amount of reporter construct was used for the HoxA5-expressing plasmid pCMVHoxA5 and the Phox2a-expressing plasmid pRC/Phox2a, which was described previously (Kim et al., 1998; Yang et al., 1998b). Cells were harvested $72 \mathrm{hr}$ after transfection, lysed by three freeze-thaw cycles, and assayed for CAT activity. To correct for differences in transfection efficiencies, CAT activity was normalized to that of $\beta$-galactosidase ( $\beta$-gal). CAT and $\beta$-galactosidase activities were assayed as described previously (Ishiguro et al., 1993; Kim et al., 1994).

Preparation of nuclear extracts. Nuclear extracts were prepared from SK-N-BE(2)C and HeLa cells according to the procedure described by Dignam et al. (1983). Cell pellets were resuspended in $20 \mathrm{mM}$ HEPES, $\mathrm{pH} 7.9,20 \%$ glycerol, $0.1 \mathrm{~m} \mathrm{KCl}, 0.2 \mathrm{~mm}$ PMSF, and $0.5 \mathrm{~mm}$ DTT and dialyzed against the same buffer. The extracts were quick-frozen in liquid nitrogen, and aliquots were stored at $-70^{\circ} \mathrm{C}$ and used within 3 months of extraction. Protein concentration of the nuclear extract was determined by the Bio-Rad (Hercules, CA) protein assay method using bovine serum albumin as a standard (Bradford, 1976).

DNase I footprinting analysis. A DNA fragment encompassing -180 to -53 bp upstream of the transcription start site was prepared by PCR and used as a probe for DNase I footprinting. For the coding strand probe, a primer, 5'-GAG TCC CCC AGA TCC CTG GGA A-3', representing the coding nucleotide sequence from -180 to $-159 \mathrm{bp}$ of the hNET gene was labeled using polynucleotide kinase and $\left[\gamma_{-}{ }^{32} \mathrm{P}\right] \mathrm{ATP}$. This labeled primer, together with the unlabeled primer, 5'-CGA TTG CAT TAA CCC AGC GCC C-3', representing the noncoding nucleotide sequence from -74 to $-53 \mathrm{bp}$ of the $h N E T$ gene, was then used for PCR. The noncoding strand probe was prepared using a labeled primer, 5'-CGA TTG CAT TAA CCC AGC GCC C-3', and the unlabeled primer 5'-GAG TCC CCC AGA TCC CTG GGA A-3'. With the pNET133(i)CAT plasmid DNA as a template, 30 cycles of PCR were performed under the following conditions: denaturation at $95^{\circ} \mathrm{C}$ for 40 sec, annealing at $55^{\circ} \mathrm{C}$ for $30 \mathrm{sec}$, and DNA synthesis at $72^{\circ} \mathrm{C}$ for $1 \mathrm{~min}$. The end-labeled product was isolated on a $7 \%$ polyacrylamide gel, as described previously (Kim et al., 1999). Labeled probe $(30,000 \mathrm{cpm}$ specific activity) was combined with $10-20 \mu l$ of nuclear extracts (containing $\sim 180 \mu \mathrm{g}$ of nuclear proteins) in $40 \mu \mathrm{l}$ of binding buffer for $25 \mathrm{~min}$ at room temperature, followed by DNase I digestion using freshly diluted DNase I in binding buffer consisting of $20 \mathrm{~mm}$ HEPES, pH 7.9, $2 \mathrm{~mm}$ $\mathrm{MgCl}_{2}, 50 \mathrm{~mm} \mathrm{NaCl}, 1 \mathrm{~mm}$ DTT, $0.1 \mathrm{~mm}$ EDTA, and 10\% glycerol. Two micrograms of poly(dI-dC) were included in each reaction as a nonspecific competitor. The amount of DNase I was empirically adjusted for each nuclear extract to produce an even pattern of partially cleaved products. The DNase I reaction was stopped by adding $100 \mu \mathrm{l}$ of stop buffer (50 mM Tris, $\mathrm{pH}$ 8.0, 1\% SDS, $10 \mathrm{~mm}$ EDTA, pH 8.0, $0.4 \mathrm{mg} / \mathrm{ml}$ proteinase $\mathrm{K}$, and $100 \mathrm{~mm} \mathrm{NaCl}$ ). Samples were then extracted twice with phenol-chloroform, and the DNA was precipitated with 3 volumes of ethanol. The DNA pellet was dried and resuspended in sequencing stop buffer $(0.05 \%$ xylene cyanol, $0.05 \%$ bromophenol blue, $10 \mathrm{~mm}$ $\mathrm{Na}_{2} \mathrm{EDTA}$, and $90 \%$ deionized formamide) and incubated at $95^{\circ} \mathrm{C}$ for 3 min. An aliquot of sample was then loaded onto a $6 \%$ polyacrylamide- 8 $\mathrm{M}$ urea sequencing gel. The same probe was subjected to parallel diges- tion without previous incubation with nuclear extracts, typically using $5-10 \%$ of the DNase I used in the presence of nuclear extracts. Location of cleaved products was determined by a Maxam-Gilbert sequencing reaction of each probe.

Electrophoretic mobility shift assay. Sense and antisense oligonucleotides corresponding to the sequences protected by DNase I with the following nucleotide sequences were synthesized for PR (Gene Link, Inc., Thornwood, NY): 5'-CCG GCC GCG CTG TCA GTC TCC ATT AGC GCT AAC AGG CTC CAG ACG GAG C-3' and 5'-GCT CCG TCT GGA GCC TGT TAG CGC TAA TGG AGA CTG ACA GCG CGG CCG G-3'. Mutant oligonucleotides included 5'-CCG GCC GCG CTG TCA GTC TCC AGC AGC GCT AAC AGG CTC CAG ACG GAG C- $3^{\prime}$ and $5^{\prime}$-GCT CCG TCT GGA GCC TGT TAG CGC TGC TGG AGA CTG ACA GCG CGG CCG G-3' for PR ${ }^{\mathrm{GCFm}}, 5^{\prime}$-CCG GCC GCG CTG TCA GTC TCC AGC AGC GCT AAC AGG CTC CAG ACG GAG C-3' and 5'-GCT $\overline{C C G}$ TCT GGA GCC TGT TAG CGC TGC TGG AGA CTG ACA GCG CGG CCG G-3' for PR ${ }^{\mathrm{HDm}}$, and 5'-CCG GCC GCG CTG TCA GTC TCC AGC AGC GCT AAC AGG CTC CAG ACG GAG C-3' and 5'-GCT CCG TCT GGA GCC TGT TAG CGC TGC TGG AGA CTG ACA GCG CGG CCG G-3' for $\mathrm{PR}^{\mathrm{PALm}}$ (underscores indicate the mutated bases). The consensus cAMP response element (CRE) oligonucleotides were described previously (Seo et al., 1996). The sense and antisense oligonucleotides for each probe were annealed, gel-purified, and ${ }^{32} \mathrm{P}$-labeled using T4 DNA kinase and used as probes in electrophoretic mobility shift assays (EMSA). EMSA and antibody coincubation experiments were performed using $30,000-50,000 \mathrm{cpm}$ of labeled probe $(\sim 0.05-0.1 \mathrm{ng})$ and nuclear extracts $(10-30 \mu \mathrm{g})$ in a final volume of $20 \mu \mathrm{l}$ of $12.5 \%$ glycerol, and (in mM): 12.5 HEPES, pH 7.9, 4 Tris-HCl, pH 7.9, $60 \mathrm{KCl}, 1$ EDTA, and 1 DTT with $1 \mu \mathrm{g}$ of poly(dI-dC) as described previously (Yang et al., 1998b). For competition-binding assays, nonradioactive competitor oligonucleotides were added in a molar excess before adding the ${ }^{32} \mathrm{P}$-labeled oligonucleotides. For supershift assays, antibody was coincubated with the nuclear extract mix for $30 \mathrm{~min}$ at $4^{\circ} \mathrm{C}$ before adding the radiolabeled probe. Antibodies used in this study included antibody against Sp1 (Santa Cruz Biotechnology, Santa Cruz, CA), antibody against HoxA5 (Babco, Richmond, CA), antibody against isl-1 (kindly provided by Dr. D. J. Drucker, Banting and Best Diabetes Centre, The Toronto Hospital, Toronto, Ontario, Canada) and phox2a-specific antibody (kindly provided by Dr. J. F. Brunet, Centre National de la Recherche Scientifique/Institut National de la Santé et de la Recherche Médicale/Universite de la Mediterranee, Marseille, France). In vitro-translated proteins were made using the TNT-coupled wheat germ extract system (Promega, Madison, WI) for in EMSA.

\section{RESULTS}

\section{The hNET 5' upstream promoter can confer NA cell type-specific transcription and contains several domains with positive or negative regulatory function}

To localize the promoter domains responsible for NA cell-specific expression of the $h N E T$ gene, we constructed a series of $5^{\prime}$ deletion mutants extending from position -9000 bp toward the start site of transcription, which along with the first intron were fused to the CAT reporter gene (Fig. 1 $A$ ). The transcriptional activities of these reporter constructs were assayed in transient transfection using the human neuroblastoma SK-N-BE(2)C (NET-positive) and the human epithelial HeLa (NET-negative) cell lines. All reporter constructs were shown to produce CAT mRNAs that were properly spliced (data not shown; Kim et al., 1999), indicating intact function of the first intron. In each experiment, cells were transfected with pRSV-CAT as a positive control, which was highly active in both SK-N-BE(2)C and HeLa cells. pNET9000(i)CAT and pNET4000(i)CAT, containing 9.0 and $4.0 \mathrm{~kb}$ upstream sequences as well as the first intron, respectively, efficiently drove reporter expression in SK-N-BE(2)C cells (Fig. 1A). In contrast, CAT expression driven by these two constructs was not significantly higher than that driven by promoterless pBLCAT3-1 control in HeLa cells (Fig. $1 A$; data not shown). These observations strongly suggest that the $4.0 \mathrm{~kb}$ upstream sequences of the $h N E T$ gene contain sufficient genetic 
A

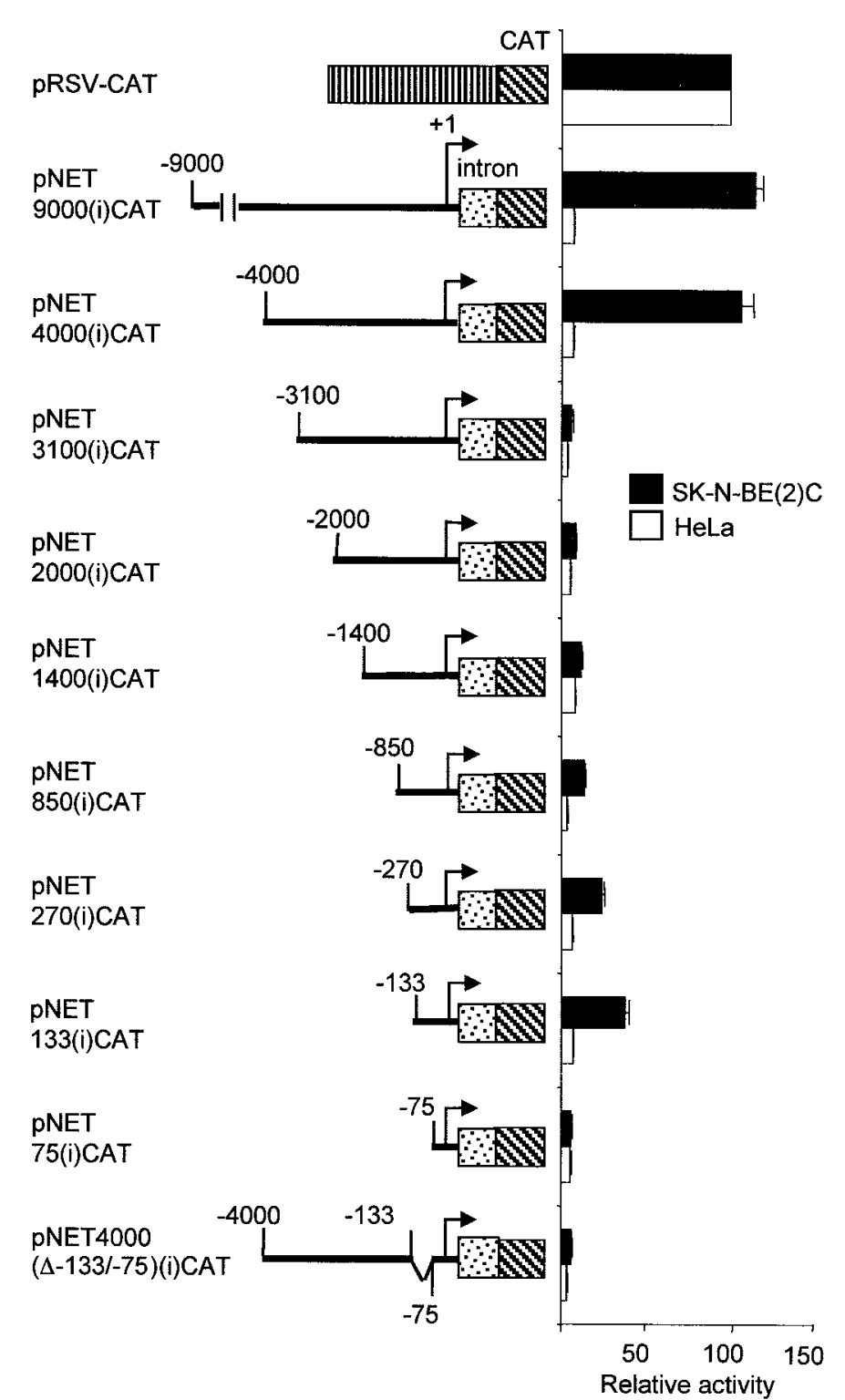

B

Relative CAT activity (\%)

\begin{tabular}{lrr}
\hline & M17 & HepG2 \\
\cline { 2 - 2 } pRSV-CAT & 100 & \\
pNET4000(i)CAT & 344 & \\
PNET3100(i)CAT & 85 & 0.5 \\
PNET 133(i)CAT & 296 & 0.5 \\
PNET 75(i)CAT & 68 & 2.2 \\
pNET4000( $4-133 /-75)(i) C A T$ & 88 & 3.9 \\
\hline
\end{tabular}

C

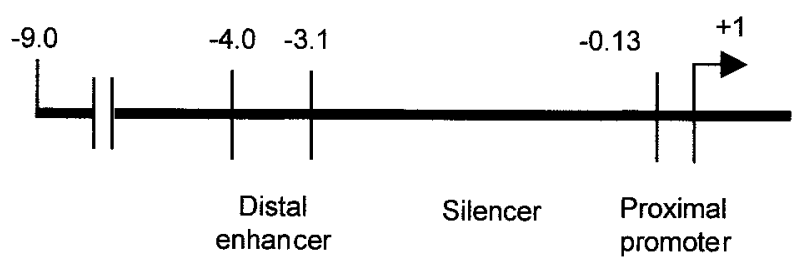

Figure 1. CAT activities of the reporter constructs containing the various lengths of $5^{\prime}$-flanking sequence of the $h N E T$ gene. $A$, The left panel shows the structural organization of the $h N E T$ gene promoter. 5 '-Flanking sequences (horizontal lines) and the first intron (dotted box) of the $h N E T$ gene were inserted upstream of the CAT coding sequence (hatched box) in the pBLCAT3-1 vector. The constructs are identified on the left along with the promoter length of each construct relative to the transcription start site (bent arrow). Deletion is designated by $\Delta$ followed by the position of the flanking nucleotides in the deleted segment ( $V$ shape). Each construct was transiently transfected into NET-positive SK-N-BE(2)C (black bar) and NET-negative HeLa (white bar) cells. Levels of CAT activity were expressed relative to that expressed by RSV-CAT plasmid and are shown in the right panel. Normalized CAT activity driven by RSV-CAT in each cell line was set to 100 to compare the relative strength of each reporter construct. The average values of six independent samples are presented as mean \pm SEM (error bars) values. The absolute levels of the normalized CAT activity of RSV-CAT were $7.8 \pm 0.9 \times 10^{4}$ and $1.1 \pm 0.2 \times 10^{5}$ cpm/OD $\mathrm{OD}_{40}$ in SK-BE(2)C and HeLa cells, respectively. Transient transfection experiments were repeated once more in triplicate, resulting in an identical pattern. $B$, Promoter activities of NET-CAT reporter constructs in SK-N-BE(2)M17 and HepG2 cell lines. Levels of CAT reporter gene activity were determined as in $A$. The absolute levels of the normalized CAT activity of RSV-CAT were $1.6 \pm 0.2 \times 10^{5}$ and $2.3 \pm$ $0.3 \times 10^{5} \mathrm{cpm} / \mathrm{OD}_{420}$ in SK-N-BE(2)M17 and HepG2 cells, respectively. Average values of CAT activities from four samples are shown. Variability among experiments was in the range of $15 \%$. C, Schematic diagrams showing the location of three potentially important regulatory domains in the $5^{\prime}$ flanking sequences of the $h N E T$ gene, including two positive regulatory domains and a negative domain.

information necessary for the NA cell-specific gene expression. Deletion of nucleotides from -4.0 to $-3.1 \mathrm{~kb}$ eliminated $\sim 90 \%$ of the promoter activity in SK-N-BE(2)C cells, suggesting that the upstream domain between -4.0 and $-3.1 \mathrm{~kb}$ contains important positive regulatory sequences. Given that this domain functions at quite a distance $(>3 \mathrm{~kb})$, it may have an enhancer activity. A series of deletion constructs showed a progressive increase in CAT activity, as nucleotide sequences between -3100 and -133 bp were eliminated. Further deletion from -133 to -75 reduced transcriptional activity to the level of a promoterless plasmid, indicating that this proximal subdomain may contain positive cis-regulatory element(s) that may be important for hNET gene expression. In HeLa cells, all deletion constructs showed background levels of reporter gene expression. To directly test the functional role of the proximal domain between -133 and -75 bp in hNET transcription, we generated an internal deletion construct, pNET4000( $\Delta-133 /-75)(\mathrm{i}) \mathrm{CAT}$, which maintains the context of $4.0 \mathrm{~kb}$ upstream sequences as well as the first intron (Fig. 1A). The level of CAT expression driven by pNET4000 $(\Delta-133 /-75)(\mathrm{i}) \mathrm{CAT}$ in SK-N-BE(2)C was $<10 \%$ of that by pNET4000(i)CAT, indicating that the proximal domain at -133 to -75 is critical for the hNET transcriptional activity.

NA cell-specific reporter expression by these constructs was further tested by transient transfection assays using additional NET-positive (SK-N-BE(2)M17) and NET-negative (HepG2) cell lines. As shown in Figure $1 B$, the $4.0 \mathrm{~kb}$ upstream sequence was able to drive cell type-specific reporter expression in these cell lines. In addition, functional importance of the upstream domain $(-4.0$ to $-3.1 \mathrm{~kb})$ and proximal domain $(-133$ to $-75 \mathrm{bp})$ 
in SK-N-BE(2)M17 cells was clearly demonstrated in our assays. Cell-specific function of the NET gene promoter was also confirmed in another NET-negative C6 cell line (data not shown).

Taken together, our transient transfection assays show that the $4.0 \mathrm{~kb}$ upstream sequences can drive reporter gene expression in a NA-specific manner and contains several important regions for the proper transcriptional function (Fig. 1C). The distal sequences from -4.0 to $-3.1 \mathrm{~kb}$ may contain an NA-specific enhancer, whereas negative elements seem to be located between -3100 and -133 bp. A proximal region between -133 and -75 bp appears to be critical for the NA-specific transcriptional activity of the $h N E T$ gene. In the light of our recent findings that critical transcription factors interact with the proximal promoter region to regulate the NA cell type-specific transcription of the human DBH gene (Seo et al., 1996; Kim et al., 1998), we have focused on the cis-regulatory elements residing between -133 and -75 bp of the $h N E T$ gene and their cognate protein factors in this study.

\section{The proximal domain between -133 and -75 bp interacts with multiple protein factors in an NA cell-specific manner}

On the basis of our transient transfection assays, we speculated that the proximal promoter domain between -133 and -75 bp may contain NA-specific cis-regulatory element(s) and may interact with transcription factor(s) in a cell-specific manner. To explore this possibility, we performed DNase I footprinting analysis using nuclear extracts isolated from SK-N-BE(2)C and HeLa cells. Indeed, a subdomain at -128 to -80 bp showed a prominent footprint only when nuclear extracts from SK-N-BE(2)C cells were used (Fig. 2A,B). Identical footprint domains were apparent when sense or antisense strands were used for analysis. These observations suggest that the upstream subdomain at -128 to -80 bp may interact with corresponding trans-acting factor(s) in a NA cell-specific manner, and that these DNA-protein interactions may be important for $h N E T$ gene transcription.

To define the potential cis-elements involved in DNA-protein interaction of the proximal domain identified, the protected sequences were searched for known transcription factor-binding motifs (Heinemeyer et al., 1998). As indicated in Figure $2 C$, the $5^{\prime}$ portion of this region contains a perfect match to the putative GC-rich factor (GCF), 5'-GGCCGCGCTG-3' (Kageyama and Pastan, 1989), and the $3^{\prime}$ portion contains a novel palindromic sequence motif, 5'-GCTCCAGACGGAGC-3' (the palindromic motif is indicated by bold letters). The middle portion includes an HD-binding core motif (5'-ATTA-3'). Interestingly, this particular region is perfectly matched with the consensus binding motifs for two HD protein factors, HoxA5 (5'-CTCCATTAGC3'; Odenwald et al., 1989) and isl-1 (5'-CATTAG-3'; Karlsson et al., 1990).

To further investigate DNA-protein interactions at the putative cis-regulatory elements in the proximal promoter region, we performed EMSAs using a 49 base pair oligonucleotide (PR) spanning nucleotides -128 to $-80 \mathrm{bp}$ as the probe. As shown in Figure $3 A$, three major DNA-protein complexes $(\mathrm{C} 1-\mathrm{C} 3)$ were evident, as well as a minor complex (C4) with the nuclear extracts isolated from the SK-N-BE(2)C cells, and the abundance of each complex increased in a concentration-dependent manner with the amount of nuclear extracts used. The specificity of all three complexes was confirmed by competition assays using a 5-, 20-, or 200-fold molar excess of the unlabeled PR oligonucleotide (Fig. $3 B$, lanes 2-4). An unrelated oligonucleotide CRE, encoding the
A

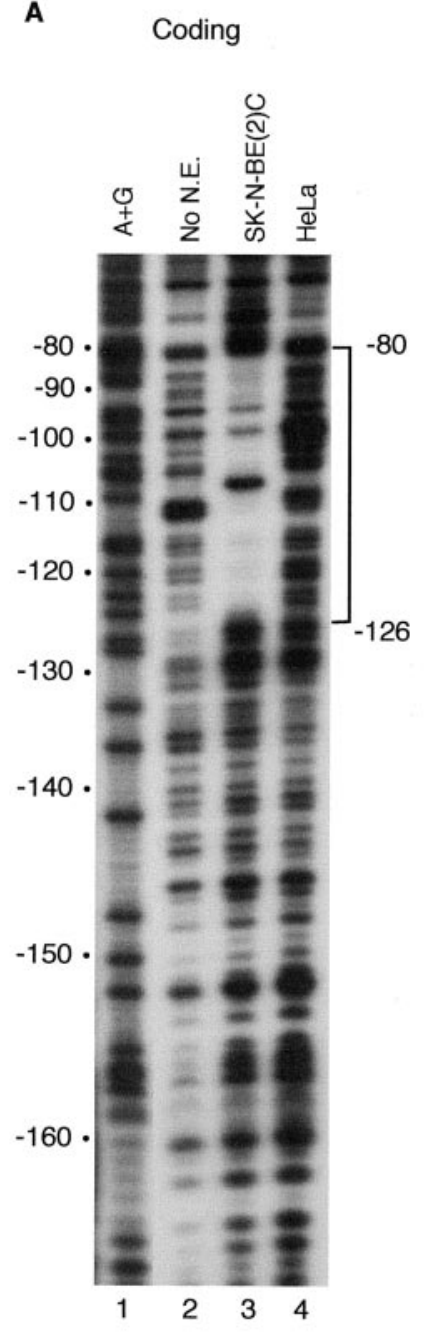

B

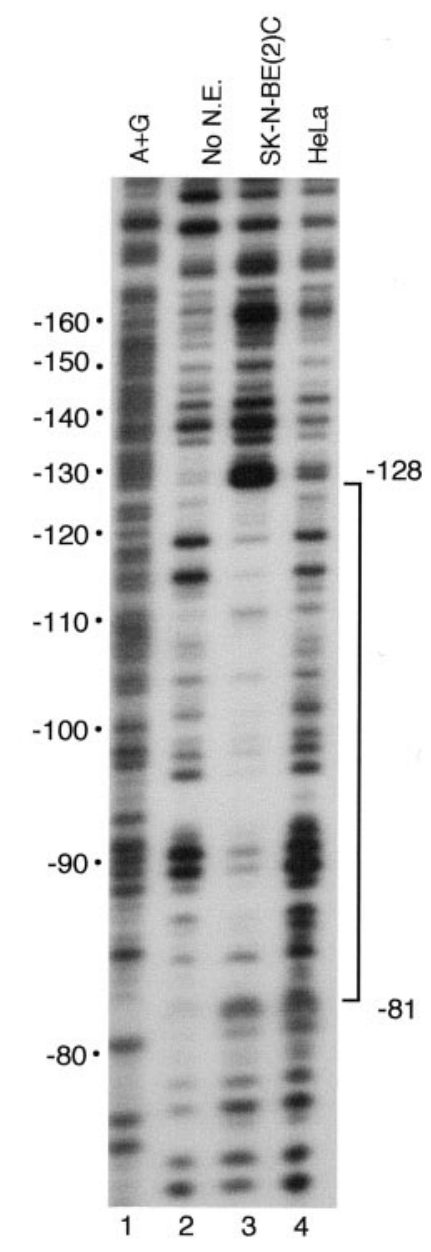

C

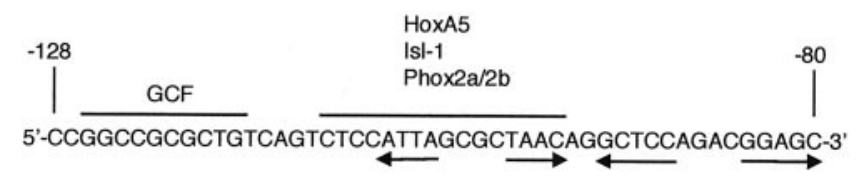

Figure 2. DNase I footprinting analysis of the $5^{\prime}$-proximal promoter region of the hNET gene. Nuclear extracts were prepared from SK-N$\mathrm{BE}(2) \mathrm{C}$ and HeLa cells and used for DNase I footprinting of the proximal promoter region of the hNET gene. The Coding $(A)$ and Noncoding $(B)$ strand probes were labeled as described in Materials and Methods. For each labeled probe, Maxam-Gilbert sequencing reaction mixtures (lane $1, G+A)$ were run in adjacent lanes. Each labeled probe was digested with DNase I in the absence (lane 2) or presence of nuclear extracts prepared from SK-N-BE(2)C (lane 3) or HeLa (lane 4) cells. Numbers to the left of the autoradiograms refer to the nucleotide positions relative to the transcription start site. $C$, Nucleotide sequences of the hNET promoter with the DNase I-protected area. The putative binding sites for GCF, HoxA5, isl-1, and Phox2a/2b are indicated with lines. Palindromic sequences are shown with arrows.

cAMP response element motif from the tyrosine hydroxylase gene (Kim et al., 1993), did not inhibit formation of any of these four complexes (Fig. 3B, lanes 14-16). When nuclear extracts isolated from HeLa cells were used in EMSA, C2-C4 but not C1 complexes were formed. The latter results were unexpected, be- 
A

$$
\begin{aligned}
& \text { BE(2)C HeLa } \\
& \text { N.E. conc }(\mu \mathrm{g})
\end{aligned}
$$

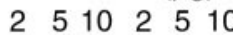

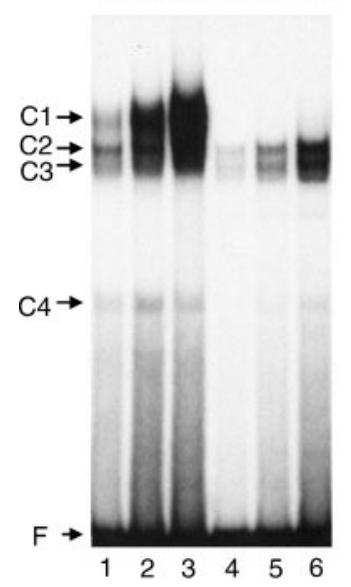

B

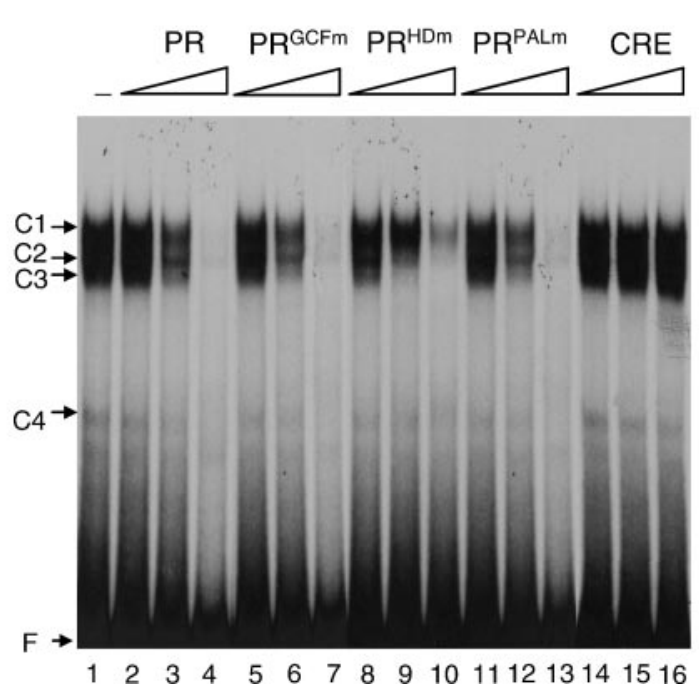

C

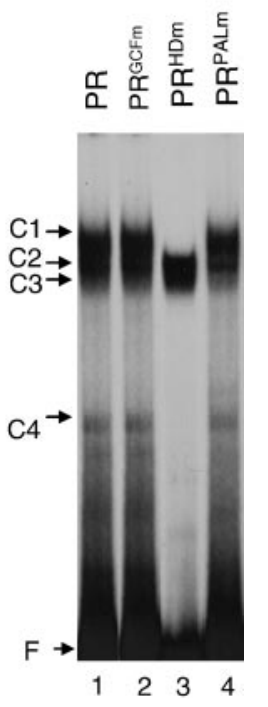

Figure 3. EMSA assay. A, PR oligonucleotide encompassing -128 to $-80 \mathrm{bp}$ was radiolabeled and incubated with $2 \mu \mathrm{g}$ (lanes 1, 4), $5 \mu \mathrm{g}($ lanes 2, 5), or $10 \mu \mathrm{g}$ (lanes 3, 6) of SK-N-BE(2)C and HeLa nuclear extract, respectively. Unbound free probe $(F)$ is indicated by an arrowhead. B, An EMSA competition experiment was performed as described in Materials and Methods. PR oligonucleotide was ${ }^{32} \mathrm{P}-\mathrm{labeled}$ and incubated with SK-N-BE(2)C nuclear extract. For competition, fivefold (lanes 2, 5, 8, 11, 14), 20 -fold (lanes 3, 6, 9, 12, 15), and 200-fold (lanes 4, 7, 10, 13, 16) molar excesses of cold nucleotides were added to a reaction mixture containing $10 \mu \mathrm{g}$ of SK-N-BE(2)C nuclear extract before the addition of the radiolabeled probe. $C$, Electrophoretic mobility shift assays were conducted using nuclear extracts from SK-N-BE(2)C nuclear extracts and labeled probes for the PR (lane 1), $\mathrm{PR}^{\mathrm{GCFm}}$ (lane 2), $\mathrm{PR}^{\mathrm{HDm}}$ (lane 3), and $\mathrm{PR}^{\mathrm{PALm}}$ (lane 4). Unbound free probe $(F)$ is indicated by an arrowhead. These EMSA and competition assays were repeated two more times with identical patterns.

cause the same proximal region did not appear protected in the DNase I footprinting assay using HeLa nuclear extracts (Fig. 2). Possible explanations for this apparent discrepancy include the following: (1) that DNase I footprinting is generally less sensitive than EMSA for detecting individual DNA-protein interaction; and (2) that proteins involved in formation of $\mathrm{C} 2$ and $\mathrm{C} 3$ may be less abundant in HeLa cells (Fig. 3A, compare lanes 1, 4, and 2, 5). Another interesting possibility is that the absence of certain transcription factor(s), e.g., involved in the formation of $\mathrm{C} 1$ or others, may prevent efficient DNA-protein interactions in non-NA cells. In any case, the $\mathrm{C} 1$ complex was only formed when SK-N-BE(2)C nuclear extracts were used, suggesting that protein factor(s) involved in the $\mathrm{C} 1$ complex may represent NA cellspecific factor(s).

\section{Transcription factors HoxA5 and Phox2a interact with the HD-binding site}

To identify the cis-regulatory element(s) that may be involved in formation of the $\mathrm{C} 1$ complex, we synthesized several mutant PR oligonucleotides containing mutations in putative cis-regulatory elements within the proximal promoter domain (Fig. 2C) and used them as competitors in EMSA (Fig. 3B). Molar excesses of the oligonucleotides $\mathrm{PR}^{\mathrm{GCFm}}$ and $\mathrm{PR}^{\mathrm{PALm}}$ containing mutations in the putative GCF-binding motif and $3^{\prime}$ palindromic sequence motif, respectively, were as effective as PR at competing with the formation of all four complexes (Fig. 3B, lanes 5-7 and 11-13). Like PR ${ }^{\mathrm{GCFm}}$ and PR ${ }^{\mathrm{PALm}}$, a molar excess of the oligonucleotide $\mathrm{PR}^{\mathrm{HDm}}$, which contains mutations at the HD core motif, efficiently inhibited formation of C2 and C3 (Fig. 3B). However, a residual signal of $\mathrm{C} 1$ consistently remained even in the presence of the highest concentration of $\mathrm{PR}^{\mathrm{HDm}}$. These findings suggest that the HD motif may be important for formation of the $\mathrm{C} 1$ complex. Notably, the oligonucleotide $\mathrm{PR}^{\mathrm{HDm}}$ was able to substantially inhibit formation of $\mathrm{C} 1$. One possible explanation is that
$\mathrm{PR}^{\mathrm{HDm}}$ containing two base substitutions may still have some binding affinity for the corresponding factor(s). This is not likely, because no $\mathrm{C} 1$ complex was formed using the oligonucleotide $\mathrm{PR}^{\mathrm{HDm}}$ as the probe (see below). Another possibility is that protein factors involved in formation of complexes $\mathrm{C} 1-\mathrm{C} 4$ bind to corresponding sequence motifs in a synergistic and interdependent manner. In this scenario, a molar excess of $\mathrm{PR}^{\mathrm{HDm}}$ will partially inhibit formation of $\mathrm{C} 1$ because of the absence of synergistic binding. When $\mathrm{PR}^{\mathrm{HDm}}$ was used as the probe, formation of $\mathrm{C} 1$ was completely abolished (Fig. $3 C$ ), further supporting the idea that the HD motif is critical for $\mathrm{C} 1$ formation. In addition, it appears that formation of $\mathrm{C} 4$ also requires the intact $\mathrm{HD}$ sequence because (1) a molar excess of $\mathrm{PR}^{\mathrm{HDm}}$ did not inhibit formation of $\mathrm{C} 4$, and (2) $\mathrm{C} 4$ was not formed when $\mathrm{PR}^{\mathrm{HDm}}$ was used as the probe.

Because the middle subdomain encompassing the HD core motif contains sequences with perfect matches to binding motifs for HoxA5 (Odenwald et al., 1989) and isl-1 (Karlsson et al., 1990), we next examined whether these proteins participated in the formation of DNA-protein complexes at this site. On the basis of sequence homologies with the Phox2a/2b-binding sites identified in the $h D B H$ gene promoter (Kim et al., 1998; Yang et al., 1998b), it is also possible that Phox2 proteins may be involved in DNA-protein interactions in this same region. To address these questions, we performed antibody coincubation experiments using the oligonucleotide $\mathrm{PR}$ as the probe. As shown in Figure $4 A$, coincubation of SK-N-BE(2)C nuclear extracts with Phox2a-specific antibody slightly diminished formation of $\mathrm{C} 1$ and generated a supershifted band (S1) in a dose-dependent manner (lanes 2-4). The specificity of this Phox 2 a antibody was previously confirmed by immunohistochemical analysis (Tiveron et al., 1996). In addition, no supershifted band was generated when HeLa nuclear extracts were used (data not shown). These obser- 
A

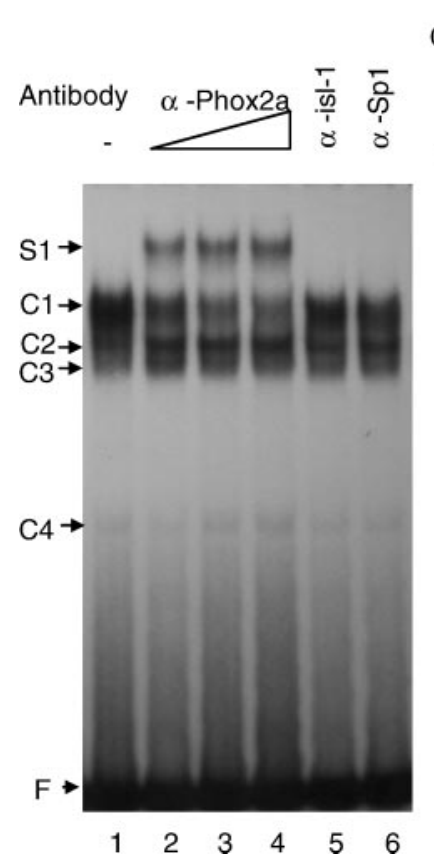

B
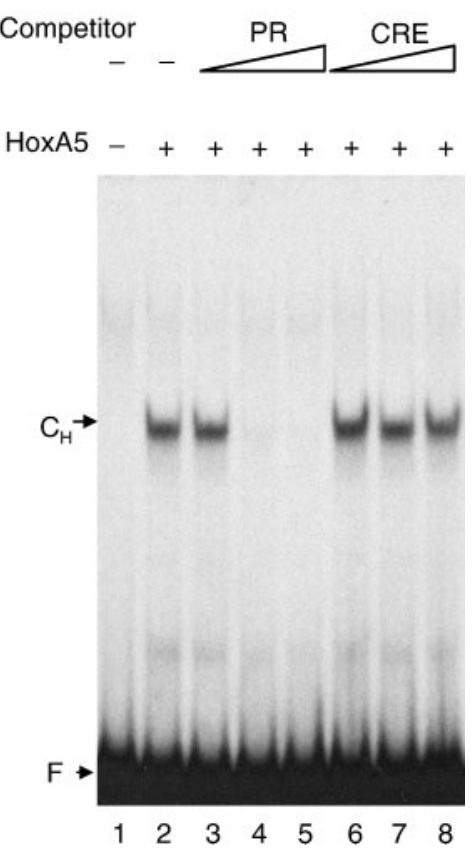

Figure 4. Both Phox2a and HoxA5 bind to the proximal promoter of the hNET gene. $A$, Oligonucleotide PR was radiolabeled and incubated with $10 \mu \mathrm{g}$ of SK-N-BE(2)C nuclear extracts in the absence (lane 1) or presence (lane 2-6) of antibodies. Increasing amounts of Phox 2a-specific antibody $(0.2 \mu \mathrm{g}$, lane $2 ; 0.5 \mu \mathrm{g}$, lane 3 ; and $1 \mu \mathrm{g}$, lane 4$)$ were coincubated with nuclear extracts. A supershifted band is denoted by $S 1$. In addition, nuclear extracts were also coincubated with $0.5 \mu \mathrm{g}$ of either isl-1 (lane 5) or Sp-1-specific antibody (lane 6). Phox2a-specific antibody by itself was unable to form any complex with the radiolabeled probes (data not shown). $B$, The same PR probe was incubated with in vitro-translated proteins in EMSA. One microliter of the in vitro-translated HoxA5 protein was incubated with the radiolabeled probe (lane 2). For competition, fivefold (lanes 3, 6), 20-fold (lanes 4, 7), and 200-fold (lanes 5, 8) molar excesses of cold nucleotides were added to the reaction mixture containing $1 \mu \mathrm{l}$ of in vitro-translated HoxA5 protein before the addition of the radiolabeled probe. $C_{H}$, Specific DNA-protein complex.

vations suggest that Phox 2a participates in formation of the $\mathrm{C} 1$ complex. In contrast, coincubation with specific antibodies against isl-1 (Fig. 4A, lane 5) or Sp1 (Fig. 4A, lane 6) neither diminished formation of complexes nor generated a supershifted band. When nuclear extract was incubated with anti-HoxA5 antibody, a faint supershifted complex was detected (data not shown). Because no specific HoxA5 antibody is available at present, we decided to directly address whether HoxA5 is able to interact with PR by in vitro-translated HoxA5 protein. As shown in Figure $4 B$, a single band $\left(C_{H}\right)$ was formed between the in vitro-translated HoxA5 and PR. A competition assay demonstrated that $\mathrm{C}_{\mathrm{H}}$ represents a specific DNA-protein complex (Fig. 4B, lanes 3-8). On the basis of these results, we conclude that Phox $2 \mathrm{a}$ and HoxA5, but not isl-1, are able to interact with the middle subdomain of the proximal promoter region.

Forced expression of HoxA5 in HeLa cells transactivates the promoter activity of the hNET gene

The observations that the HD-binding motif within the proximal promoter domain can interact with Phox2a and HoxA5 prompted us to hypothesize that these HD proteins may regulate NET transcription. To test this, Phox2a-, Phox $2 \mathrm{~b}-$, and HoxA5-expressing vectors (Fig. $5 A$ ) were transiently cotrans-

A

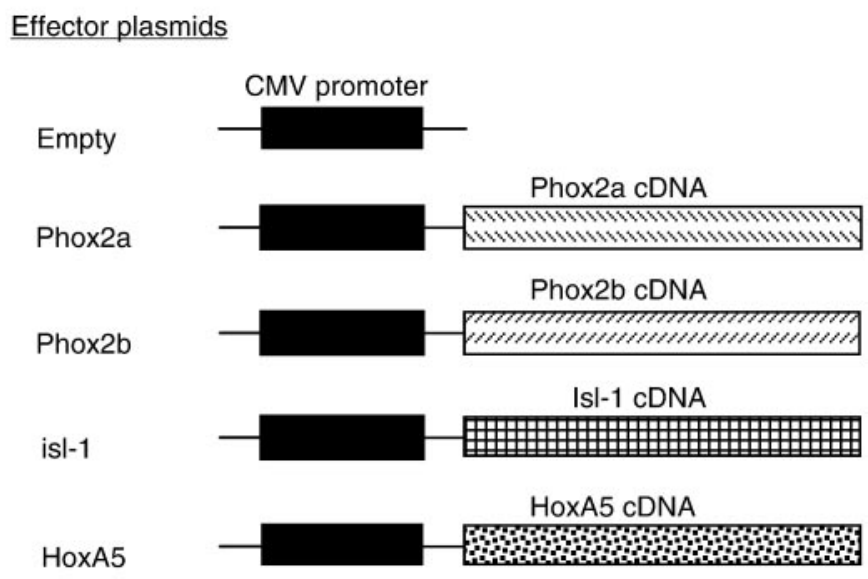

Reporter plasmids

pNET133(i)CAT

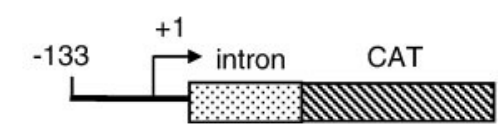

2.6DBHCAT

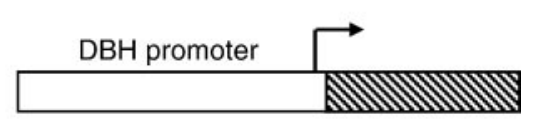

B

C

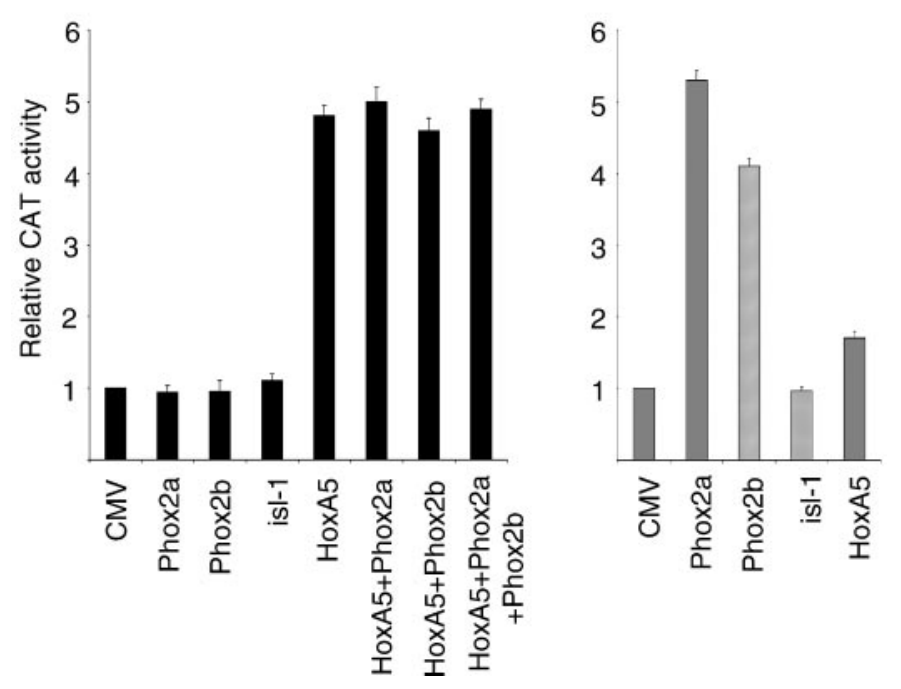

Figure 5. HoxA5 transactivates the hNET promoter. $A$, Diagram of effector and reporter plasmids. pRC/CMV (Invitrogen) was used as the empty control plasmid. $B, C$, HeLa cells were transiently cotransfected with reporter and effector plasmids. The pNET133(i)CAT reporter construct $(B)$ and 2.6DBHCAT reporter construct $(C)$ (Ishiguro et al., 1993) containing the $2.6 \mathrm{~kb}$ of upstream sequence of the human DBH gene were used as reporter plasmids. The amount of effector plasmids is described as the molar ratio compared with the reporter plasmid. Samples were harvested $48 \mathrm{hr}$ after transfection, and relative CAT activities were determined as described in Materials and Methods. To compare fold transactivation directly, basal CAT activity driven by the reporter construct in each cell line was set to 1 . Here, the molar ratio of effector plasmid to reporter plasmid was 1 . The bent arrow at +1 indicates the transcriptional start point and direction. 


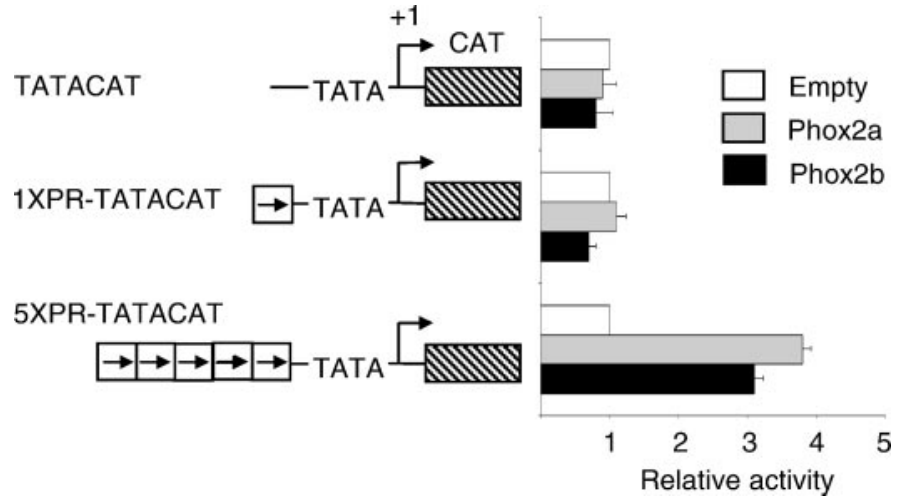

Figure 6. Multiple copies of the HD-binding site can mediate transactivation of the reporter gene activity by Phox 2 proteins. Left panel, Diagrams of the various reporter plasmids. TATA-CAT (Yang et al., 1998b) is a minimal DBH-CAT reporter plasmid that contains the TATA box and the transcription start site of the human DBH gene. A single copy or five copies of oligonucleotide PR was cloned upstream of the TATA box, resulting in 1XP-TATACAT or 5XP-TATACAT, respectively. HeLa cells were transiently cotransfected with reporter plasmids and empty plasmid pRC/CMV, pRC/Phox2a, pRC/Phox2b, pCMVHoxA5, or pCMVisl-1 at a molar ratio of 1 . Basal CAT activity driven by an empty vector was set to 1.0 to compare transactivation by Phox $2 \mathrm{a}$, Phox $2 \mathrm{~b}$, HoxA5, or isl-1. The bent arrow at +1 indicates the transcriptional start point and direction.

fected along with the pNET133(i)CAT construct to HeLa cells. In agreement with previous studies, cotransfection of either Phox2a or Phox $2 b$ prominently increased the transcriptional activity of 2.6DBHCAT but failed to activate hNET promoter function (Kim et al., 1999). In contrast, forced expression of HoxA5 in this cell line activated the transcriptional activity of pNET133(i)CAT up to fivefold (Fig. 5B). Interestingly, exogenous expression of HoxA5 did not significantly regulate the transcriptional activity of 2.6DBHCAT, indicating that transactivation of hNET promoter function by HoxA5 may be promoter-specific. To test whether HoxA5 and Phox2a may synergistically regulate transcription of the NET gene, HoxA5 was cotransfected with either Phox2a or Phox2b along with pNET133(i)CAT. Neither Phox2a nor Phox2b was able to potentiate transactivating function of HoxA5 (Fig. $5 B$ ). In addition, cotransfection of isl-1 expression plasmid did not affect the transcriptional activity of pNET133(i)CAT or 2.6DBHCAT. Together with our antibody coincubation experiments, these results do not support a role of isl-1 in hNET gene transcription.

Our cotransfection results with Phox2a conflict with the observation that Phox $2 \mathrm{a}$ interacts with the middle subdomain of the proximal promoter region of the hNET gene. One possible explanation is that one copy of the Phox2a-binding site may be insufficient for clear transactivation of the promoter activity in a transient transfection assay, although it may be regulated in the in vivo situation. In this context, it is to be noted that the $\mathrm{DBH}$ gene promoter, which is transactivated 5- to 10 -fold by forced expression of Phox2a, contains multiple Phox2a-binding sites (Kim et al., 1998; Yang et al., 1998b). Therefore, it may be necessary to test multiple copies of the HD-binding site to confirm the possible regulation by Phox2a in a transient cotransfection assay. To this end, we subcloned a single copy (1XPR-TATACAT) and five tandem copies (5XPR-TATACAT) of the double-stranded oligonucleotide PR in front of the minimal promoter region of the

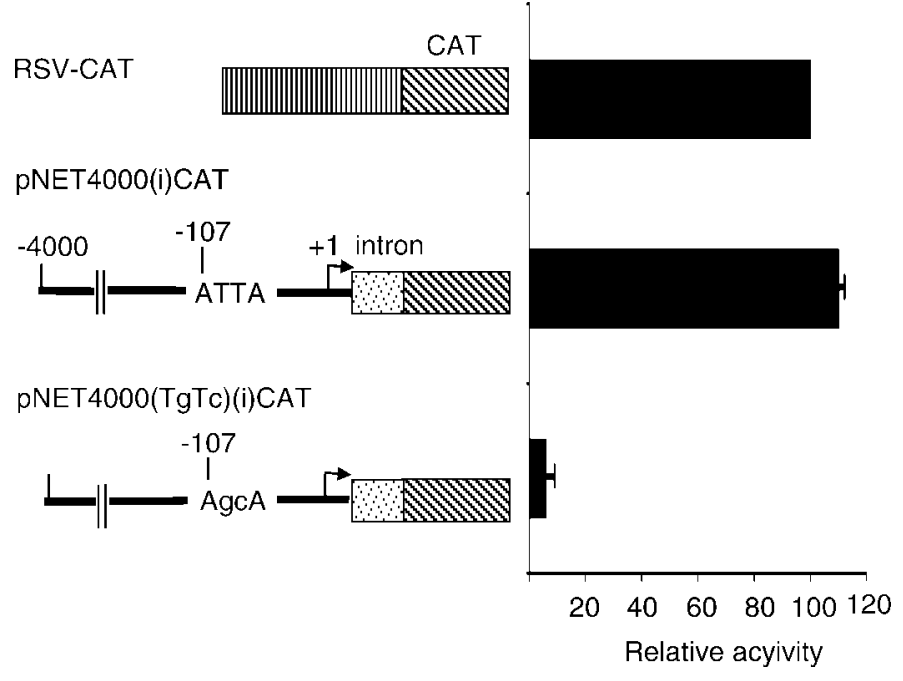

Figure 7. Effect of mutating the HD motif on promoter activity. SK-N-BE(2)C cells were transiently transfected with the wild-type [pNET4000(i)CAT] or site-directed mutant construct [pNET4000 (TgTc)(i)CAT] as indicated. CAT activities were normalized to the $\beta$-galactosidase activity driven by the cotransfected RSV $\beta$-galactosidase plasmid. The normalized CAT activity driven by pRSV-CAT was set to 100 to compare the relative activity of the wild-type and mutated constructs. The bent arrow at +1 indicates the transcriptional start point and direction.

DBH gene (Fig. 6). This minimal DBH promoter, containing only the TATA box and transcription start site, is fully characterized by footprinting assay and functional analysis (Kim et al., 1998; Hwang et al., 2001). Because it has no promoter activity by itself, it is suitable to test the potential function of the HD-binding site. As expected from the data in Figure 5, forced expression of Phox2a was unable to activate reporter gene expression driven by the 1XPR-TATACAT plasmid (Fig. 6). However, cotransfection of the Phox2a or Phox $2 \mathrm{~b}$ expression plasmid increased reporter gene expression driven by the 5XPR-TATACAT plasmid by threefold to fourfold in HeLa cells (Fig. 6). Together with EMSA results (Fig. 4), these results suggest that HoxA5 and Phox2 proteins may directly activate hNET gene transcription in vivo by interacting with the HD-binding site residing within the proximal promoter domain.

The HD-binding core motif residing in the proximal promoter is crucial for the hNET promoter function

On the basis of DNA-protein interactions by Phox2 and HoxA5 protein factors and their transcriptional activities, we hypothesized that the HD-binding core motif within the proximal promoter may be critical for the NA cell-specific promoter function of the hNET gene. To address this possibility, we mutated the HD core motif in the context of pNET4000(i)CAT and compared its transcriptional activity with that of the wild-type construct in the SK-N-BE(2)C cell line. Strikingly, this mutation diminished reporter gene expression $>90 \%$, compared with that driven by the wild-type pNET4000(i)CAT construct (Fig. 7). We conclude that the cis-regulatory element encompassing the HD core motif, residing at the middle of the proximal promoter domain, interacts with HD proteins, including HoxA5 and Phox2 protein factors, and may play a critical role in NA cell type-specific transcription of the $h N E T$ gene. 


\section{DISCUSSION}

\section{Identification of three promoter domains in the $5^{\prime}$ upstream sequences of the hNET gene}

We have recently shown that the $9.0 \mathrm{~kb}$ upstream sequences of the hNET gene are critical for NA cell type-specific promoter activity, whereas the first intron is necessary for high-level transcription (Kim et al., 1999; Kim et al., 2001). In the present study, using transient transfection assays of a series of deletion and site-directed mutant reporter constructs in NET-positive and NET-negative cell lines, we have identified three functional promoter domains that may be important for $h N E T$ gene regulation. Specifically, within $4.0 \mathrm{~kb}$ of upstream hNET promoter sequences, a proximal domain-spanning sequence from -133 to $-75 \mathrm{bp}$ and a distal upstream domain spanning sequence from -4.0 and $-3.1 \mathrm{~kb}$ may possess NA cell-specific positive regulatory function, whereas a middle domain between -3100 and $-133 \mathrm{bp}$ appears to have general silencer function. Furthermore, NAspecific transcription of the $h N E T$ gene appears to require both the distal and proximal domains, because deletion of either diminished most of the hNET promoter activity in the NETpositive cell lines (Fig. 1). In contrast, the deletion mutations had a marginal effect, if any, in the NET-negative cells. Given that the distal upstream domain is transcriptionally active at quite a distance $(>3 \mathrm{~kb})$, it may work as an enhancer. It is well known that cell type-specific transcription of various eukaryotic genes, especially when expression is highly restricted, often involves cooperative interactions between several regulatory elements (Simonet et al., 1993; Cockell et al., 1995; Kruse et al., 1995; Sanchez et al., 1995), and such interactions between enhancer(s) and promoter elements have been described previously (Pinkert et al., 1987; Crenshaw et al., 1989). Our results indicate that the distal upstream domain and the proximal domain may synergistically interact to regulate NA cell-specific transcription of the $h N E T$ gene. Therefore, definition of functional cis-regulatory elements and their cognate protein factors working in each of the two promoter domains is crucial for understanding the molecular mechanisms underlying the NA cell type-specific hNET gene expression.

\section{Identification of potential cis-regulatory elements residing in the proximal promoter domain}

To obtain further insights on molecular mechanisms of hNET gene regulation, we have focused on analyzing the proximal domain in greater detail in the studies described here for the following two reasons. First, on the basis of analogy with the NA cell-specific $h D B H$ gene promoter, which contains critical cisregulatory elements within the proximal promoter area (Ishiguro et al., 1993; Seo et al., 1996; Kim et al., 1998), similar cis elements may exist within a proximal domain of the $h N E T$ gene and may govern NA cell-type specific $h N E T$ gene transcription. Second, the defined proximal promoter domain of the $h N E T$ gene identified above is much shorter than the upstream enhancer region and, hence, would facilitate the identification of cis element(s) and their cognate transcription factors. Indeed, a subdomain at -128 to $-80 \mathrm{bp}$ was found to be prominently footprinted by nuclear proteins from SK-N-BE(2)C but not by those from HeLa cells (Fig. 2). This result is not only consistent with deletional analysis suggesting NA-specific promoter function but also provided the first clue that this footprinted area may represent DNA-protein interactions that are critical for the NA cell-specific transcriptional activity of the $h N E T$ gene. A computer search of the nucleotide sequences contained within the footprinted region using the Transfac database (Heinemeyer et al., 1998) identified putative protein-binding sites for the GCF (5'-GGCCGCGCTG3'; Kageyama and Pastan, 1989) in the 5' portion of the footprinted domain and binding sites for isl-1 (5'-CATTAG-3'; Karlsson et al., 1990) and HoxA5 (5'-CTCCATTAGC-3'; Odenwald et al., 1989) in the middle domain. Although the $3^{\prime}$ region shows no clear homology to any of previously reported protein-binding motifs, it contains a perfect palindromic sequence (5'GCTCCAGACGGAGC-3') with four intervening nucleotides (Fig. 2C).

In EMSA analysis using the oligonucleotide PR, which encompasses the footprinted subdomain, four specific DNA-protein complexes $(\mathrm{C} 1-\mathrm{C} 4)$ were produced when incubated with SK-N$\mathrm{BE}(2) \mathrm{C}$ nuclear extracts. When HeLa nuclear extracts were used, $\mathrm{C} 2-\mathrm{C} 4$ complexes were formed with less intensity, and $\mathrm{C} 1$ was not detected. Thus, $\mathrm{C} 1$ appears to represent NA cell type-specific DNA-protein interactions. Both EMSA using a mutant probe and competition assays demonstrated that $\mathrm{C} 1$ and $\mathrm{C} 4$ are mainly formed by DNA-protein interaction(s) at the middle subdomain that contains the HD core motif (Figs. 3 and 4). At present, it is not clear which cis elements are responsible for $\mathrm{C} 2$ and $\mathrm{C} 3$, because mutation at the GCF motif or the $3^{\prime}$ palindromic motif did not apparently affect formation of complexes (Fig. 3). Taken together, our results suggest that multiple protein factors may interact with several cis-regulatory elements residing in the proximal promoter domain and may control the NA cell-specific transcription of the hNET gene. Among these, the middle part encompassing the HD binding core motif appears to interact with HD protein factors, including HoxA5, Phox2a, or both, to generate the $\mathrm{C} 1$ complex in an NA cell-specific manner.

\section{HoxA5 and Phox2 proteins may interact with the proximal promoter domain and may regulate NA cell type-specific transcriptional activity of the hNET gene}

On the basis of the potential sequence motifs in the footprinted area (Fig. 2), we wished to address whether HoxA5 and isl-1 as well as Phox2a may interact with the proximal promoter domain and directly transactivate the hNET promoter activity. Antibody coincubation experiments and EMSA using in vitro-translated protein indicated that HoxA5, Phox2a, or both, but not isl-1, may directly participate in producing the $\mathrm{C} 1$ complex. Interestingly, forced expression of HoxA5 prominently transactivated the hNET promoter activity in NET-negative cells (Fig. $5 B$ ). The HoxA5 (formerly Hox-1.3) gene encodes a nuclear phosphoprotein capable of binding to specific DNA sequences (Odenwald et al., 1989). Recently, it has been reported that the HoxA5 protein behaves as a transcription activator for multiple target genes, including its own gene (Odenwald et al., 1989; Zhao et al., 1996), a Purkinje cell-specific gene (Sanlioglu et al., 1998), p53 (Raman et al., 2000b), and the progesterone receptor gene (Raman et al., 2000a). During embryogenesis the expression of HoxA5 shows progressive restriction. Although all primitive structures express HoxA5 protein in early developmental stages, the CNS and PNS are the main areas of HoxA5 expression in the late gestation stage (Tani et al., 1989). Our data suggest, for the first time to our knowledge, that HoxA5 may participate in transcriptional activation of the hNET gene.

In contrast to HoxA5, forced expression of Phox2a failed to activate hNET promoter activity (Fig. 5) (Kim et al., 1999). This observation thus does not support a direct role of Phox2a in NET gene expression. However, in vitro transient transfection analysis does not always recapitulate patterns of in vivo gene regulation, at 
least in part, because of the lack of intact chromatin structure. For example, it was found that the $5^{\prime}$ upstream sequence of the tyrosine hydroxylase $(T H)$ gene can direct cell type-specific reporter expression in transgenic mouse experiments (Banerjee et al., 1992; Min et al., 1994) but not in transient transfection analysis (Yang et al., 1998a). In addition, it is possible that Phox $2 \mathrm{a} / 2 \mathrm{~b}$ may be necessary but not sufficient for transcriptional activation of the target genes. In this case, forced expression of Phox $2 \mathrm{a} / 2 \mathrm{~b}$ may be able to induce target gene expression only in certain cellular contexts. Finally, transactivation of promoter activity by Phox $2 \mathrm{a} / 2 \mathrm{~b}$ may be detectable in transient transfection assays only when the promoter contains multiple binding sites. For example, the DBH promoter, known to be transactivated by Phox $2 \mathrm{a} / 2 \mathrm{~b}$ in transient transfection assays, contains multiple Phox2a/2b-binding sites (Kim et al., 1998; Yang et al., 1998b). To explore this possibility, we generated a reporter construct containing one or five tandem copies of the oligonucleotide PR in front of the reporter CAT gene (Fig. 6). Although cotransfection of Phox $2 \mathrm{a}$ or Phox $2 \mathrm{~b}$ failed to transactivate the one copy construct, it prominently increased reporter gene expression driven by the construct containing five copies of PR. It is thus possible that Phox $2 \mathrm{a} / 2 \mathrm{~b}$ may participate in direct transcriptional activation of the $h N E T$ gene in vivo by interacting with the proximal promoter region. However, the clear role of Phox $2 a / 2 b$ on the onset of NET expression in the brain awaits further investigation, including in vivo analysis of an inducible knock-out or transgenic animal model. Recent evidence indicated that onset of NET expression precedes the onset of neural crest stem cell emigration from the neural tube and contributes to the later expression of biosynthetic enzymes, TH and $\mathrm{DBH}$, in the peripheral nervous system (Ren et al., 2001).

In summary, this study characterizes NA-specific promoter function of the $h N E T$ gene and identifies three domains potentially important for $h N E T$ gene transcription: an upstream enhancer between -4.0 and $-3.1 \mathrm{~kb}$, a proximal domain between -133 and $-75 \mathrm{bp}$, and a middle silencer domain between these two domains. Using both DNase I footprinting analysis and EMSA, DNA-protein interactions in the proximal domain were characterized. Among several DNA-protein complexes (C1-C4), $\mathrm{C} 1$ was formed between the HD core motif and HD factors such as Phox2a and HoxA5 in an NA cell-specific manner and appears to be crucial for NET gene transcription. In support of this, mutation of the HD motif dramatically diminished the promoter function of the $h N E T$ gene. The NET plays a key role for termination of NA neurotransmission, and regulation of NET gene expression is thought to be physiologically important. The present study will serve as the basis for further investigation of the molecular mechanisms underlying NET gene regulation.

\section{REFERENCES}

Axelrod J, Kopin IJ (1969) The uptake, storage, release and metabolism of noradrenaline in sympathetic nerves. Prog Brain Res 31:21-32.

Banerjee SA, Hoppe P, Brilliant M, Chikaraishi DM (1992) 5' flanking sequences of the rat tyrosine hydroxylase gene target accurate tissuespecific, developmental, and transsynaptic expression in transgenic mice. J Neurosci 12:4460-4467.

Bradford MM (1976) A rapid and sensitive method for the quantitation of microgram quantities of protein utilizing the principle of protein-dye binding. Anal Biochem 72:248-254.

Bruss M, Porzgen P, Bryan-Lluka LJ, Bonisch H (1997) The rat norepinephrine transporter: molecular cloning from PC12 cells and functional expression. Brain Res Mol Brain Res 52:257-262.

Cockell M, Stolarczyk D, Frutiger S, Hughes GJ, Hagenbuchle O, Wellauer PK (1995) Binding sites for hepatocyte nuclear factor 3 beta or 3 gamma and pancreas transcription factor 1 are required for efficient expression of the gene encoding pancreatic alpha-amylase. Mol Cell Biol 15:1933-1941.

Comer AM, Qi J, Christie DL, Gibbons HM, Lipski J (1998) Noradrenaline transporter expression in the pons and medulla oblongata of the rat: localisation to noradrenergic and some $\mathrm{C} 1$ adrenergic neurones. Brain Res Mol Brain Res 62:65-76.

Crenshaw III EB, Kalla K, Simmons DM, Swanson LW, Rosenfeld MG (1989) Cell-specific expression of the prolactin gene in transgenic mice is controlled by synergistic interactions between promoter and enhancer elements. Genes Dev 3:959-972.

Cubells JF, Kim KS, Baker H, Volpe BT, Chung Y, Houpt TA, Wessel TC, Joh TH (1995) Differential in vivo regulation of mRNA encoding the norepinephrine transporter and tyrosine hydroxylase in rat adrenal medulla and locus ceruleus. J Neurochem 65:502-509.

Dignam JD, Lebovitz RM, Roeder RG (1983) Accurate transcription initiation by RNA polymerase II in a soluble extract from isolated mammalian nuclei. Nucleic Acids Res 11:1475-1489.

Friedman JI, Adler DN, Davis KL (1999) The role of norepinephrine in the pathophysiology of cognitive disorders: potential applications to the treatment of cognitive dysfunction in schizophrenia and Alzheimer's disease. Biol Psychiatry 46:1243-1252.

Guo LH, Yang RC, Wu R (1983) An improved strategy for rapid direct sequencing of both strands of long DNA molecules cloned in a plasmid. Nucleic Acids Res 11:5521-5540.

Heinemeyer T, Wingender E, Reuter I, Hermjakob H, Kel AE, Kel OV, Ignatieva EV, Ananko EA, Podkolodnaya OA, Kolpakov FA, Podkolodny NL, Kolchanov NA (1998) Databases on transcriptional regulation: TRANSFAC, TRRD and COMPEL. Nucleic Acids Res 26:362-367.

Henikoff S (1984) Unidirectional digestion with exonuclease III creates targeted breakpoints for DNA sequencing. Gene 28:351-359.

Hoyle GW, Mercer EH, Palmiter RD, Brinster RL (1994) Cell-specific expression from the human dopamine beta-hydroxylase promoter in transgenic mice is controlled via a combination of positive and negative regulatory elements. J Neurosci 14:2455-2463.

Hwang D-Y, Carlezon WA, Isacson O, Kim KS (2001) A high-efficiency synthetic promoter that drives transgene expression selectively in noradrenergic neurons. Hum Gene Ther 12:1731-1740.

Ishiguro H, Kim KT, Joh TH, Kim KS (1993) Neuron-specific expression of the human dopamine beta-hydroxylase gene requires both the cAMP-response element and a silencer region. J Biol Chem 268:17987-17994.

Kageyama R, Pastan I (1989) Molecular cloning and characterization of a human DNA binding factor that represses transcription. Cell 59:815-825.

Karlsson O, Thor S, Norberg T, Ohlsson H, Edlund T (1990) Insulin gene enhancer binding protein Isl-1 is a member of a novel class of proteins containing both a homeo- and a Cys-His domain. Nature 344:879-882.

Kim CH, Kim HS, Cubells JF, Kim KS (1999) A previously undescribed intron and extensive $5^{\prime}$ upstream sequence, but not Phox2a-mediated transactivation, are necessary for high level cell type-specific expression of the human norepinephrine transporter gene. J Biol Chem 274:6507-6518.

Kim CH, Ardayfio P, Kim KS (2001) An e-box motif residing in the exon/intron 1 junction regulates both transcriptional activation and splicing of the human norepinephrine transporter gene. J Biol Chem 276:24797-24805.

Kim HS, Seo H, Yang C, Brunet JF, Kim KS (1998) Noradrenergicspecific transcription of the dopamine beta-hydroxylase gene requires synergy of multiple cis-acting elements including at least two Phox $2 \mathrm{a}-$ binding sites. J Neurosci 18:8247-8260.

Kim KS, Park DH, Wessel TC, Song B, Wagner JA, Joh TH (1993) A dual role for the cAMP-dependent protein kinase in tyrosine hydroxylase gene expression. Proc Natl Acad Sci USA 90:3471-3475.

Kim KS, Ishiguro H, Tinti C, Wagner J, Joh TH (1994) The cAMPdependent protein kinase regulates transcription of the dopamine betahydroxylase gene. J Neurosci 14:7200-7207.

Kruse F, Rose SD, Swift GH, Hammer RE, MacDonald RJ (1995) Cooperation between elements of an organ-specific transcriptional enhancer in animals. Mol Cell Biol 15:4385-4394.

Lee CM, Javitch JA, Snyder SH (1983) Recognition sites for norepinephrine uptake: regulation by neurotransmitter. Science 220:626-629.

Lingen B, Bruss M, Bonisch H (1994) Cloning and expression of the bovine sodium- and chloride-dependent noradrenaline transporter. FEBS Lett 342:235-238.

Lorang D, Amara SG, Simerly RB (1994) Cell-type-specific expression of catecholamine transporters in the rat brain. J Neurosci 14:4903-4914.

Min N, Joh TH, Kim KS, Peng C, Son JH (1994) 5' upstream DNA sequence of the rat tyrosine hydroxylase gene directs high-level and tissue-specific expression to catecholaminergic neurons in the central nervous system of transgenic mice. Brain Res Mol Brain Res 27:281-289.

Morin X, Cremer H, Hirsch MR, Kapur RP, Goridis C, Brunet JF (1997) Defects in sensory and autonomic ganglia and absence of locus coer- 
uleus in mice deficient for the homeobox gene Phox2a. Neuron 18:411-423.

Nishimura M, Sato K, Shimada S, Tohyama M (1999) Expression of norepinephrine and serotonin transporter mRNAs in the rat superior cervical ganglion. Brain Res Mol Brain Res 67:82-86.

Odenwald WF, Garbern J, Arnheiter H, Tournier-Lasserve E, Lazzarini RA (1989) The Hox-1.3 homeo box protein is a sequence-specific DNA-binding phosphoprotein. Genes Dev 3:158-172.

Ordway GA, Widdowson PS, Smith KS, Halaris A (1994) Agonist binding to alpha 2-adrenoceptors is elevated in the locus coeruleus from victims of suicide. J Neurochem 63:617-624.

Owens MJ, Morgan WN, Plott SJ, Nemeroff CB (1997) Neurotransmitter receptor and transporter binding profile of antidepressants and their metabolites. J Pharmacol Exp Ther 283:1305-1322.

Pacholczyk T, Blakely RD, Amara SG (1991) Expression cloning of a cocaine- and antidepressant-sensitive human noradrenaline transporter. Nature 350:350-354.

Papp M, Nalepa I, Vetulani J (1994) Reversal by imipramine of betaadrenoceptor up-regulation induced in a chronic mild stress model of depression. Eur J Pharmacol 261:141-147.

Phillips JK, Dubey R, Sesiashvilvi E, Takeda M, Christie DL, Lipski J (2001) Differential expression of the noradrenaline transporter in adrenergic chromaffin cells, ganglion cells and nerve fibres of the rat adrenal medulla. J Chem Neuroanat 21:95-104.

Pinkert CA, Ornitz DM, Brinster RL, Palmiter RD (1987) An albumin enhancer located $10 \mathrm{~kb}$ upstream functions along with its promoter to direct efficient, liver-specific expression in transgenic mice. Genes Dev $1: 268-276$.

Ramamoorthy S, Prasad PD, Kulanthaivel P, Leibach FH, Blakely RD, Ganapathy V (1993) Expressing of a cocaine-sensitive norepinephrine transporter in the human placental syncytiotrophoblast. Biochemistry 32:1346-1353.

Raman V, Tamori A, Vali M, Zeller K, Korz D, Sukumar S (2000a) HOXA5 regulates expression of the progesterone receptor. J Biol Chem 275:26551-26555.

Raman V, Martensen SA, Reisman D, Evron E, Odenwald WF, Jaffee E, Marks J, Sukumar S (2000b) Compromised HOXA5 function can limit p53 expression in human breast tumours. Nature 405:974-978.

Ren ZG, Porzgen P, Zhang JM, Chen XR, Amara SG, Blakely RD, Sieber-Blum M (2001) Autocrine regulation of norepinephrine transporter expression. Mol Cell Neurosci 17:539-550.

Ressler KJ, Nemeroff CB (1999) Role of norepinephrine in the pathophysiology and treatment of mood disorders. Biol Psychiatry 46:1219-1233.

Ressler KJ, Nemeroff CB (2000) Role of serotonergic and noradrenergic systems in the pathophysiology of depression and anxiety disorders. Depress Anxiety 12:2-19.

Sacchetti G, Bernini M, Bianchetti A, Parini S, Invernizzi RW, Samanin $\mathrm{R}$ (1999) Studies on the acute and chronic effects of reboxetine on extracellular noradrenaline and other monoamines in the rat brain. Br J Pharmacol 128:1332-1338.

Sanchez HB, Yieh L, Osborne TF (1995) Cooperation by sterol regula- tory element-binding protein and $\mathrm{Sp} 1$ in sterol regulation of low density lipoprotein receptor gene. J Biol Chem 270:1161-1169.

Sanlioglu S, Zhang X, Baader SL, Oberdick J (1998) Regulation of a Purkinje cell-specific promoter by homeodomain proteins: repression by engrailed-2 vs. synergistic activation by Hoxa5 and Hoxb7. J Neurobiol 36:559-571.

Schroeter S, Apparsundaram S, Wiley RG, Miner LH, Sesack SR, Blakely RD (2000) Immunolocalization of the cocaine- and antidepressantsensitive L-norepinephrine transporter. J Comp Neurol 420:211-232.

Seo H, Yang C, Kim HS, Kim KS (1996) Multiple protein factors interact with the cis-regulatory elements of the proximal promoter in a cell-specific manner and regulate transcription of the dopamine betahydroxylase gene. J Neurosci 16:4102-4112.

Shannon JR, Flattem NL, Jordan J, Jacob G, Black BK, Biaggioni I, Blakely RD, Robertson D (2000) Orthostatic intolerance and tachycardia associated with norepinephrine-transporter deficiency. N Engl J Med 342:541-549.

Shaskus J, Greco D, Asnani LP, Lewis EJ (1992) A bifunctional genetic regulatory element of the rat dopamine beta-hydroxylase gene influences cell type specificity and second messenger-mediated transcription. J Biol Chem 267:18821-18830.

Simonet WS, Bucay N, Lauer SJ, Taylor JM (1993) A far-downstream hepatocyte-specific control region directs expression of the linked human apolipoprotein E and C-I genes in transgenic mice. J Biol Chem 268:8221-8229.

Tani M, Odenwald WF, Lazzarini RA, Friedrich Jr VL (1989) Progressive restriction in the distribution of the Hox-1.3 homeodomain protein during embryogenesis. J Neurosci Res 24:457-469.

Tiveron MC, Hirsch MR, Brunet JF (1996) The expression pattern of the transcription factor Phox2 delineates synaptic pathways of the autonomic nervous system. J Neurosci 16:7649-7660.

Valarche I, Tissier-Seta JP, Hirsch MR, Martinez S, Goridis C, Brunet JF (1993) The mouse homeodomain protein Phox 2 regulates Ncam promoter activity in concert with Cux/CDP and is a putative determinant of neurotransmitter phenotype. Development 119:881-896.

Xu F, Gainetdinov RR, Wetsel WC, Jones SR, Bohn LM, Miller GW, Wang YM, Caron MG (2000) Mice lacking the norepinephrine transporter are supersensitive to psychostimulants. Nat Neurosci 3:465-471.

Yang C, Kim HS, Seo H, Kim KS (1998a) Identification and characterization of potential cis-regulatory elements governing transcriptional activation of the rat tyrosine hydroxylase gene. J Neurochem 71:1358-1368.

Yang C, Kim HS, Seo H, Kim CH, Brunet JF, Kim KS (1998b) Pairedlike homeodomain proteins, Phox $2 \mathrm{a}$ and Phox $2 \mathrm{~b}$, are responsible for noradrenergic cell-specific transcription of the dopamine betahydroxylase gene. J Neurochem 71:1813-1826.

Zellmer E, Zhang Z, Greco D, Rhodes J, Cassel S, Lewis EJ (1995) A homeodomain protein selectively expressed in noradrenergic tissue regulates transcription of neurotransmitter biosynthetic genes. J Neurosci 15:8109-8120.

Zhao JJ, Lazzarini RA, Pick L (1996) Functional dissection of the mouse Hox-a5 gene. EMBO J 15:1313-1322. 